\title{
Cooperative Learning In Virtual Environments: The Jigsaw Method In Statistical Courses
}

\author{
Manuel Vargas-Vargas, Ph.D., University of Castilla-La Mancha, Spain \\ José Mondéjar-Jiménez, Ph.D., University of Castilla-La Mancha, Spain \\ María-Letica Meseguer Santamaría, Ph.D., University of Castilla-La Mancha, Spain \\ Jose-Luis Alfaro-Navarro, Ph.D., University of Castilla-La Mancha, Spain \\ Gema Fernández-Avilés, Ph.D., University of Castilla-La Mancha, Spain
}

\begin{abstract}
This document sets out a novel teaching methodology as used in subjects with statistical content, traditionally regarded by students as "difficult". In a virtual learning environment, instructional techniques little used in mathematical courses were employed, such as the Jigsaw cooperative learning method, which had to be adapted to the peculiarities of the subject. The aim of this methodological project is to adapt the teaching of statistical courses to the new European Higher Education Area.
\end{abstract}

Keywords: e-Learning; Jigsaw; European Higher Education; Statistical Courses

\section{INTRODUCTION}

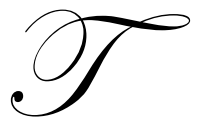
technologies (ICTs) so as to adapt to the new scenarios in educ
Messeguer, Navarro, Damian-Reyes \& Favela, 2010; Pozzi, 2010)

Since 1998, with the Sorbonne declaration, a series of meetings have been conducted by the European Ministers of Education, to establish the European Higher Education Area (EHEA). Today, the EHEA is a reality, and Spain is in adaptation process (Mondéjar, Mondéjar \& Vargas, 2006). One of the most important developments in this area consists of the incorporation of new information and communication technologies (ICTs) to traditional teaching, which should allow it to adapt teaching methods and adjust its to the new educational settings (Mondéjar, Mondéjar \& Vargas, 2007).

Therefore, using Internet and ICT, which should be considered as generators of flexible and adaptable training spaces, we have developed new teaching options that combine different learning resources (Mondéjar \& Vargas, 2010). It is, therefore, essential to understand how various teaching techniques work in the new virtual framework.

To meet this challenge, methodological strategies which, though not recent, have enjoyed only a limited sphere of application are now becoming widespread in university education, notably including those linked to cooperative learning. This term refers to an alternative way of structuring the teaching/learning process to as to make up the deficiencies involved in the exclusive use of traditional techniques with a greater focus on achieving results than on acquiring competencies (Huang, Huang, \& Hsieh, 2008). Cooperative learning, by contrast, seeks to develop positive interdependence, face-to-face interaction, individual accountability, social skills and autonomous group processing (Johnson \& Johnson, 1989a). 
Cooperative learning has been the subject of numerous research projects since the $70 \mathrm{~s}$, when the first research on its specific applications came out (Slavin, 1991). With cooperative methods and techniques, the aim (Johnson \& Johnson, 1989b) is to foster positive interdependence, face-to-face interaction, individual accountability, social skills and autonomous group processing.

There are various techniques with which teachers may devise tasks to be carried out with the cooperative learning method, as Walters (2000) set out, who highlights four main cooperative learning models. These models are notable for their flexibility in application to a range of subjects, ages, learning situations, etc.

Walters's four models are: Jigsaw, Student Team Learning, Learning Together, and Group Investigation.

In this sense, working in cooperative groups may provide several gains for students. Cooperative groups may improve students' social competence, foremost their ability to collaborate with peers (Bratt, 2008) and they may improve academic achievement among students (Lazarowitz, Hertz-Lazarowitz, \& Baird, 1994). Some authors also suggest that as a result of cooperation, students will develop more empathy, in particular towards weaker students (Aronson \& Patnoe, 1997).

\section{APPLICATION OF THE JIGSAW METHOD IN MATHEMATICAL COURSES}

In the teaching of mathematical courses, and as a result of the convergence process in the EHEA, there has been a widespread reflection on goals -both, short-term (successful completion of the course) and medium-term (knowledge and skills acquired for use in professional activity) - and on course contents. The use of new information and communication technologies is renewing teaching methods in Spanish universities with virtual tools of increasing scope that are ever more widely employed. All these factors contribute to the adoption of instructional strategies and methods which, though developed two decades ago, are only now beginning to be applied in the teaching of statistics (Perkins \& Saris, 2001).

There are precedents in the literature showing the use of cooperative learning in mathematics courses (Lampert, 1990; Yackel, Cobb, \& Wood, 1991). Learning activities like restructuring problems, integrating different points of view, giving explanations and analysing misconceptions, collaborative practice, high intensity of student activities and controversial discussions, which are typically used when engaging in cooperative methods, can be labelled as cognitive elaboration (Souvignier \& Kronenberger, 2007).

\subsection{Structure in a virtual learning environment}

In our process of adaptation to new educational scenarios we opted for a teaching/learning process based on e-learning, notable for integrating the use of new technologies and traditional instructional methods. Some of the most valuable benefits of this type of instruction in our case are the possibility of remote lesson attendance, the existence of a virtual meeting space for the performance of work and greater dynamism in learning.

Although researchers have explored structured cooperative learning in online environments to some degree, the need remains for understanding how educators can best apply specific cooperative learning models, like Jigsaw, to online learning environments in ways that capitalize on and overcome the unique characteristics of this medium (Weidman \& Bishop, 2009).

This organization allows the course to be followed in a virtual way, with students organizing their own time and rate of work, which is especially useful for students who cannot regularly attend classes for reasons of employment or compatibility with other studies or mobility programmes such as Erasmus. But also for those who regularly attend classes it is useful to have an overview of the course, including the materials, course schedule (calendar), information on events, and means of contact with lecturers and classmates (email, chat, forums, individual or group virtual tutorials, etc.).

Schaeffer \& Cates (1996) suggested Jigsaw as one technique appropriate for computer-mediated cooperative learning, in which the computer could allow for effective student communication and teacher guidance 
without the need for the synchronous, face-to-face interaction traditional to this and other cooperative learning methods (Weidman \& Bishop, 2009).

Accordingly in the second stage of the course we opt for a problem-based learning approach, using the Jigsaw method (Aronson \& Patnoe, 1997). The course organization now changes and new roles are assigned to teachers and students.

The empirical work has been developed in Spanish university students. These students study for the first time in their studies to a statistics course. This is the first experience in quantitative materials held in the Spanish university.

The students organize themselves into learning groups (basic groups) with five members each. For any one problem they are provided with the operating principles, the goals to be met by each group and the basic information structured in blocks. Each member of the basic group must choose a block and, using the materials posted on the Moodle page, organize his/her own learning, seeking additional information, laying out his/her subject area and structuring his/her presentation of the block.

A second stage consists of meetings of the "expert teams". This point facilitates further development of the self-learning process and a higher degree of organization in the information prepared by each member. As a product of this stage, each expert group is encouraged to develop a Wiki on their field of study -a web page setting out all the information gathered on the subject area. These Wikis are highly flexible pages, loosely structured and open to all the "experts".

The method's third stage consists of meetings of the "basic groups". Each expert transmits information on his/her particular subject area to the other members. Thus he/she is responsible for facilitating learning by the rest of the team. Each student in turn receives structured information on the other subject areas, studied in the same way as his/her own. The objective of this stage, in addition to summarizing and presentation skills, is for the team to learn to cooperate and to arrive at a reasonable level of understanding of each subject area and a grasp of the subject as a whole.

Finally the groups are asked to show what they have learned. On one hand the results are evaluated, with all team members having to successfully complete a questionnaire covering the subject's basic content, and show their ability to solve real, specific problems presented to them. As the learning process is cooperative, a mark is awarded to the group as a whole - in respect of the basic knowledge acquired according to the combined individual marks, and with the joint solving of a real problem, assessed both by the teachers and by the other teams.

The ultimate aim of the methodology used is the acquisition by students of a set of general and specific competencies and skills and a basic mastery of mathematical techniques, which are used increasingly in fields of work linked to economics and business. Accordingly, given the diversity of course objectives, we adopt diverse teaching strategies so as to foster each of the skills included in the course plan.

\section{DISCUSSION AND CONCLUSIONS}

This document presents the general pedagogical organization of a course with mathematical content, with special reference to the use of a particular cooperative learning technical - Jigsaw - within a virtual learning environment. Among the cooperative learning methods to be found in specialized writings in the field, we opted for this one in particular because of the ease with which its operating principles can be learned by students, its ease of application in virtual environments and the possibility of also using other simultaneous and linked learning strategies (Panitz, 1999).

After a first stage of presenting core materials and general methods, the instructional methodology presented above has various benefits: 
- $\quad$ The adoption of a problem-based learning approach facilitates meaningful learning in which students progressively build solutions on the basis of the basic tools learned previously. Thus we break away from the traditional structure based on memorization and introduce students to the logic of scientific research, as well as developing their capacity for continuing learning.

- $\quad$ The use of the Jigsaw method allows students to approach a mathematical discipline free of the widespread prejudices (Bayot et al., 2005).

- $\quad$ The need to cooperate with classmates, peer learning and the absence of a solution supplied by the teacher all increase flexibility and student involvement in the learning process.

- $\quad$ The creation of Wikis by expert groups represents a challenge for students, who have to undertake a guided search for information, assimilate that information and organize it for their classmates.

- The structuring of the course in a virtual environment allows location and time barriers to be overcome.

For testing the benefits of the Jigsaw method in statistical courses, it was applied to a course on Statistical Quality Control with five units, each one comprised four lessons. The goal of our study is to examine whether this cooperative method can increased motivation and student satisfaction, as pointed out Barkley, Cross \& Major (2005). It is necessary to analyze the question of the students' motivation and attitude towards quantitative subject and test what types of teaching strategy can improve students' performance, because students' attitude towards statistics can either be an important obstacle to learning the subject or a significant advantage (Phillips, 1980).

We use a questionnaire about attitude towards statistics (Bayot et al., 2005), with two subscales, one affective and the other evaluative, both bi-dimensional in structure. In the affective subscale, one factor measures the degree of interest in the subject and the other the level of anxiety of the students when studying statistics problems. In the evaluative subscale, one component measuring the utility students perceive for their current studies and the other the utility for their future professional career.

But, the origins of the student's negative attitude can be linked with an inappropriate learning method of high formalized disciplines (Mondéjar, Vargas \& Bayot, 2008). To analyse the links between the student's attitude toward statistics and the learning methods, we have used the Study Process Questionnaire R-SPQ-2F of Biggs, Kember \& Leung (2001). This questionnaire consists of twenty items, reflecting motives and strategic learning behaviour of students. Subjects were asked to indicate how true each item was of them by rating a 5-point Likerttype scale. We have presented both questionnaires to two groups of students, the first following the Jigsaw method and the second one, a traditional methodology.

Table 1. Attitude toward Statistic Questionnaire

\begin{tabular}{|c|c|c|c|c|c|c|c|c|c|}
\hline & & \multirow[b]{2}{*}{$\mathrm{N}$} & \multirow[b]{2}{*}{ Mean } & \multirow[b]{2}{*}{$\begin{array}{l}\text { Standard } \\
\text { Desviation }\end{array}$} & \multirow[b]{2}{*}{ Error } & \multicolumn{2}{|l|}{ I.C. at $95 \%$} & \multirow[b]{2}{*}{ Minimum } & \multirow[b]{2}{*}{ Maximum } \\
\hline & & & & & & Lower limit & $\begin{array}{l}\text { Upper } \\
\text { limit }\end{array}$ & & \\
\hline \multirow[t]{3}{*}{ Dimension 1: Interest } & Jigsaw & 61 & -.0132067 & 1.06085703 & .13582882 & -2849048 & .2584914 & -2.45496 & 1.77776 \\
\hline & traditional & 68 & .0118472 & .95772396 & .11614109 & -.2199714 & .2436657 & -2.22565 & 2.51849 \\
\hline & Total & 129 & .0000000 & 1.00389865 & .08838835 & -.1748914 & .1748914 & -2.45496 & 2.51849 \\
\hline \multirow[t]{3}{*}{ Dimension 2: Anxiety } & Jigsaw & 61 & -.1020780 & .98490445 & .12610409 & -.3543237 & .1501678 & -2.35275 & 1.58387 \\
\hline & traditional & 68 & .0915699 & 1.01915970 & .12359127 & -.1551193 & .3382591 & -2.58273 & 2.50758 \\
\hline & Total & 129 & .0000000 & 1.00389865 & .08838835 & -.1748914 & .1748914 & -2.58273 & 2.50758 \\
\hline \multirow{3}{*}{$\begin{array}{l}\text { Dimension 3:: } \\
\text { Current Utility }\end{array}$} & Jigsaw & 61 & -.1296914 & 1.06325432 & .13613577 & -.4020035 & .1426207 & -2.84423 & 2.16061 \\
\hline & traditional & 68 & .1163408 & .94017314 & .11401274 & -.1112296 & .3439112 & -1.90728 & 2.16061 \\
\hline & Total & 129 & .0000000 & 1.00389865 & .08838835 & -.1748914 & .1748914 & -2.84423 & 2.16061 \\
\hline \multirow{3}{*}{$\begin{array}{l}\text { Dimension 4: } \\
\text { Professional Utility }\end{array}$} & Jigsaw & 61 & .0423494 & 1.08803712 & .13930888 & -.2363098 & .3210087 & -4.46226 & 2.00522 \\
\hline & traditional & 68 & -.0379899 & .92851166 & .11259858 & -.2627376 & .1867578 & -2.35591 & 2.18222 \\
\hline & Total & 129 & .0000000 & 1.00389865 & .08838835 & -.1748914 & .1748914 & -4.46226 & 2.18222 \\
\hline
\end{tabular}


The results for the attitude questionnaire (table 1) show that the first group haves a lower level of interest and anxiety about statistics, although the differences were not statistically significant. On the utility factors, also not significant, the first group receives a lesser extent the present utility of statistics for their studies, but consider it more useful for future professional development.

For R-SPQ-2F questionnaire, the results are very different. As shown in Table 2, students who have taken a virtual environment have a greater identification with the in-depth study of statistics, while those who have followed a traditional teaching method have a higher value on the factor related to superficial study.

Table 2. R-SPQ-2F Questionnaire

\begin{tabular}{|c|c|c|c|c|c|c|c|c|c|}
\hline & & & & & & I.C. at 9 & & & \\
\hline & & $\mathrm{N}$ & Mean & $\begin{array}{l}\text { Standard } \\
\text { Desviation }\end{array}$ & Error & Lower limit & $\begin{array}{l}\text { Upper } \\
\text { limit }\end{array}$ & Minimum & Maximum \\
\hline Deep Study & Jigsaw & 61 & 1.1047238 & .66296348 & .08488378 & .9349310 & 1.2745166 & .39078 & 3.15629 \\
\hline & traditional & 68 & .0326983 & 1.07493811 & .13035539 & -2274921 & .2928888 & -2.87179 & 3.15629 \\
\hline & Total & 129 & .5396251 & 1.04859655 & .09232378 & .3569467 & .7223035 & -2.87179 & 3.15629 \\
\hline Superficial Study & Jigsaw & 61 & -.0051874 & 1.08606350 & . 13905618 & -2833411 & .2729664 & -2.78590 & 1.92636 \\
\hline & traditional & 68 & 1.0644813 & .35274098 & .04277613 & .9790998 & 1.1498629 & .51075 & 1.92636 \\
\hline & Total & 129 & .5586690 & .95156163 & .08378033 & .3928953 & .7244427 & -2.78590 & 1.92636 \\
\hline
\end{tabular}

The results for attitude towards statistics indicate that the cooperative learning methodology provides some improvement, but they are not statistically conclusive. In contrast, the results offer stronger evidence of differences in the case of the study processes, a finding that could contribute in part to explaining the differences in attitudes.

Therefore, it is important to continue to formulate and refine existing design guidelines, and strengthen them by providing evidence of their impact in several contexts (Kali, Levin-Peled \& Dori, 2009). In summary, though Jigsaw is an organized learning method, the combination of peer teaching, the development of Wikis by "expert groups", the problem-based learning process and the use of an e-learning environment give the proposed methodology presented here great flexibility, catering for the widest range of student interests, attitudes and skills.

\section{AUTHOR INFORMATION}

Manuel Vargas-Vargas, PhD in Economics by University of Castilla-La Mancha and Degree in Mathematics by University of Granada. Associate Professor in Statistics at Statistics Department. Faculty of Economics and Business Administration of Albacete, University of Castilla-La Mancha (Spain). E-mail: Manuel.Vargas@uclm.es.

Research Interest: State-space models, educational, tourism and environment.

José Mondéjar-Jiménez, European $\mathrm{PhD}$ in Economics and Degree in Business Administration by University of Castilla-La Mancha. Associate Professor in Statistics at Statistics Department. Faculty of Social Sciences of Cuenca. University of Castilla-La Mancha (Spain). E-mail: Jose.Mondejar@uclm.es.

Research Interest: Regional analysis, educational, tourism and environment.

María-Leticia Meseguer-Santamaría, European PhD in Economics, MBA in Economics and Degree in Business Administration by University of Castilla-La Mancha. Assistant Professor in Statistics at Statistics Department. Faculty of Economics and Business Administration of Albacete. University of Castilla-La Mancha (Spain). E-mail: MLeticia.Meseguer@uclm.es.

Research Interest: disability, women studies, educational and tourism. 
José-Luis Alfaro-Navarro, $\mathrm{PhD}$ in Economics and Degree in Business Administration by University of Castilla-La Mancha. Assistant Professor at Statistics Department. Faculty of Economics and Business Administration of Albacete. University of Castilla-La Mancha (Spain). E-mail: JoseLuis.Alfaro@uclm.es.

Research Interest: statistical quality control, regional analysis and agrarian prices.

Gema Fernández-Avilés, Holder of a European $\mathrm{PhD}$ in Economics and Business Administration from the University of Castile-La Mancha in Spain, she is currently an Assistant Lecturer in Statistics at the Department of Statistics, Faculty of Law and Social Sciences, at the University of Castile-La Mancha, Spain. E-mail: Gema.FAviles@uclm.es.

Research Interests: qualitative data, higher education, geostatistics and tourism.

\section{REFERENCES}

1. Aronson, E., Patnoe, S. (1997). The jigsaw classroom: Building cooperation in the classroom (2nd ed.). New York: Addison Wesley Longman.

2. Barkley, E. F., Cross, K. P., Major, C. H. (2005). Collaborative learning techniques: A handbook for college faculty. San Francisco: Jossy-Bass.

3. Bayot, A., Mondéjar, J., Mondéjar, J.A., Monsalve, F., Vargas, M. (2005). The Difficulties of Learning Concepts in the Social Sciences. In Misztal, M. and M. Trawinski (eds.). Studies in Teacher Education: Psichopedagogy (pp. 242-258). Wydawnictwo Naukowe Akademii Pedagogicznej: Kraków.

4. Biggs, J. B., Kember, D., Leung, D. Y. P. (2001): The revised two-factor study proccess questionnaire: RSPQ-2F, British Journal of Educational Psychology, 71: 133-149.

5. Bratt, C. (2008). The Jigsaw classroom under test: No effect on intergroup relations evident, Journal of Community \& Applied Social Psychology, 18(5):403-419.

6. Carroll, D. W. (1986). Use of the Jigsaw technique in laboratory and discussion classes, Teaching of Psychology, 13:208-210.

7. Goldsworthy, R. (2000). Collaborative Classrooms, Learning \& Leading with Technology, 27 (4). Available in: http:///www.iste.org/L\&L/archive/vol27/no4/

8. Huang, Y.M., Huang, T.C., Hsieh, M.Y. (2008). Using annotation services in a ubiquitous Jigsaw cooperative learning environment, Educational Technology \& Society, 11(2):3-15.

9. Johnson, D. W., Johnson, R. T. (1989a). Cooperative Learning: What Special Education Teachers Needs to Know, Pointer, 33(2):5-10.

10. Johnson, D. W., Johnson, R. T. (1998b). Cooperative Learning, Values, and Culturally Plural Classrooms, Cooperative Learning Center at the University of Minnesota. Minneapolis. Available in: http://www.clcrc.com/pages/CLandD.html

11. Johnson, D. W., Johnson, R. T. (1990). Using Cooperative Learning In Math. In N. Davidson (Ed). Cooperative Learning In Mathematics: A Handbook For Teachers, (pp. 219-250). New York: AddisonWesley.

12. Kali, Y., Levin-Peled, R., Dori, Y. J. (2009). The role of design-principles in designing courses that promote collaborative learning in higher-education, Computers in Human Behavior, 25(5):1067-1078.

13. Lampert, M. (1990). When the problem is not the question and the solution is not the answer: Mathematical knowing and teaching, American Journal of Educational Research, 27:29-63.

14. Lazarowitz, R., Hertz-Lazarowitz, R., Baird, J. H. (1994). Learning science in a cooperative settingacademic-achievement and affective outcomes, Journal of Research in Science Teaching, 31(10):1121-1131.

15. Messeguer, R., Navarro, L., Damian-Reyes, P., Favela, J. (2010). Context awareness for collaborative learning with uncertainty management, Journal of universal computers science, 16(12):1556-1576.

16. Millis, B. J., Cottell, P. G. (1998). Cooperative learning for higher education faculty. Phoenix, AZ: Oryx Press.

17. Mondéjar, J., Mondéjar, J. A., Vargas, M. (2006). Implantación de la metodología e-learning en la docencia universitaria: una experiencia a través del proyecto Campus Virtual, Revista Latinoamericana de Tecnología Educativa, 5(1):59-71. Available in: http://campusvirtual.unex.es/cala/editio/ 
18. Mondéjar, J. A., Mondéjar, J., Vargas, M. (2007). Virtual education in traditional universities: experience in the university of Castilla_la Mancha, Revista Iberoamericana de Educación a Distancia, 7(2):207-228.

19. Mondéjar, J., Vargas, M. (2010). Determinant factors of attitude towards quantitative subjects: Differences between sexes, Teaching and Teacher Education, 26:688-693.

20. Mondéjar, J., Vargas, M., Bayot, A. (2008). Medición de la actitud hacia la estadística. Influencia de los procesos de estudio. Revista Electrónica de Investigación Psicoeducativa, 6 (3): 729-748.

21. Odasz, F. (2000). Collaborative Internet Tools, Learning \& Leading with Technology, 27(4). Available in: http:///www.iste.org/L\&L/archive/vol27/no4/

22. Panitz, T. (1997). Sixty-seven benefits of cooperative learning, Available in: http://home.capecod.net/ tpanitz/starterpages/articles.htm

23. Perkins, D. V., Saris, R. N. (2001). A jigsaw classroom technique for undergraduate statistics courses, Teaching of Psychology, 28:111-113.

24. Phillips, J. (1980). La lógica del pensamiento estadístico. México, El Manual Moderno.

25. Pozzi, F. (2010). Using jigsaw and case study for supporting online collaborative learning, Computers \& Education, 55 (1):67-75.

26. Schaeffer, R. S., Cates, W. M. (1996). Cooperative software for the Internet. In M. R. Simonson, M. Hays, S. Hall (Eds.), Proceedings of selected research and development presentations at the 1996 National Convention of the Association for Educational Communications and Technology (pp. 674-682). Ames: Iowa State University.

27. Sharan, Y., Sharan, S. (1992). Expanding Cooperative Learning Through Cooperative Learning, New York: Teachers College Press.

28. Slavin, R. E. (1983). When does cooperative learning increase student achievement?, Psychological Bulletin, 94:429-445.

29. Slavin, R. E. (1991). Group rewards make groupwork work, Educational Leadership, 48:89-91.

30. Souvignier, E., Kronenberger, J. (2007): Cooperative learning in third graders' Jigsaw groups for mathematics and science with and without questioning training, British Journal of Educational Psychology, 77:755-771.

31. Walters, L. S. (2000). Four Leading Models, Harvard Education Letter's Research Online, Available in: http://www.edletter.org/past/issues/2000-mj/models.shtml.

32. Weidman, R., Bishop, M. J. (2009). Using the Jigsaw Model to Facilitate Cooperative Learning in an Online Course, Quarterly Review of Distance Education, 10(1):51-64.

33. Yackel, E., Cobb, P., Wood, T. (1991). Small group interactions as a source of learning opportunities in second-grade mathematics, Journal for Research in Mathematics Education, 22:390-408. 
NOTES 